\title{
Bioactive compounds and acceptance of cookies made with Guava peel flour
}

\author{
Silvana Maria Michelin BERTAGNOLLI ${ }^{1 \star}$, Márcia Liliane Rippel SILVEIRA², Aline de Oliveira FOGAÇA", \\ Liziane UMANN ${ }^{1}$, Neidi Garcia PENNA ${ }^{2}$
}

\begin{abstract}
The use of fruit industrial waste in the processing new foods represents an important new step for the food industry. This study aimed to develop cookie recipes using different amounts of guava peel flour (GPF) levels (30\%, 50\%, and $70 \%)$ to evaluate the proximate composition, and the phenolic compound, lycopene, and $\beta$-carotene levels in the cookies and flour and to evaluate the cookie sensory acceptance. The results demonstrated low moisture, lipid and carbohydrate contents in the flour and cookies. GPF was considered rich in fiber, ash, polyphenols, and $\beta$-carotene. The sensory analysis showed satisfactory acceptance of the cookies containing 30\% GPF regarding the aroma, flavor, and texture attributes. The cookies containing 50\% and $70 \%$ GPF received satisfactory acceptance regarding to aroma only. In conclusion, GPF can be used to partially replace wheat flour in the preparation of cookies to improve the nutritional quality without affecting the product sensory quality.
\end{abstract}

Keywords: polyphenols; sensory analysis; proximate composition.

\section{Introduction}

Currently, the food sector has to deal with a high rate of food waste produced by industrial fruit processing of various products such as jams, wines, juices, ice cream, sweets, and others. The use of waste from industrial processing of fruits is an important new step for the food industry. Reuse guava processing waste, such as guava peel, could increase the raw material yield, thus minimizing the problems caused by the disposal of large amount of industrial waste and also expand alternative food production (Kobori \& Jorge, 2005). An economically and technologically feasible alternative would be to produce flour from guava peels in order to either make new products, such as cookies, or partially replace wheat flour to improve the product's nutritional quality since guava has good antioxidant potential and high vitamin $\mathrm{C}$ and phenolic compound levels and pigments such as $\beta$-carotene and lycopene (Oliveira et al., 2011).

Numerous studies have been carried out in order to replace wheat with flour made from waste from fruit residues in the preparation of bakery products such as biscuits like cookies due to economic constraints, business requirements, new consumption trends, and specific eating habits (Aquino et al., 2010; Perez \& Germani, 2007). Fruit residues can be important sources of nutrients and, to satisfy consumer demand for healthier products, many food industries are finding ways to add functional ingredients to their products (Assis et al., 2009). According to Aquino et al. (2010), when added to foods, such ingredients are associated tohealthy products by customers since they are able to modify/enhance the taste, texture, aroma, color, and nutritional value of the products produced. Santucci et al. (2003) stated that the mixture of flour made from unconventional products with wheat flour improves the nutritional quality of cookies and may even improve their palatability making them more accepted by consumers. Souza et al. (2008) concluded that the flour prepared from passion fruit shell can be used in the enrichment of products such as breads, cookies, and Granola bars improving their nutritional and technological qualities, besides being an alternative to reduce the by-product waste in the food industry. Among the bakery products, biscuits are one the most commonly used products in the incorporation of different ingredients for their nutritional diversification. This is mainly due to factors such as ease of use, good nutritional quality, availability of different varieties, and affordable cost. Accordingly, products such as cookies are a good subject for the studies on mixed flour, due to economic or nutritional reasons (Assis et al., 2009).

However, it is important that the waste selected to integrate mixed flours are evaluated in terms of chemical composition and nutrition for the development of technology that enables its use in cookies efficiently, without any damage to the quality of products. Therefore, this study aimed to develop cookie recipes using different amounts of guava peel flour (GPF) and to evaluate its proximate composition and the content of polyphenols, lycopene, and $\beta$-carotenein the flour and in the cookies, as well as to evaluate the cookie sensory acceptance.

\section{Materials and methods}

Guava (Psidium guajavaL. var. Paluma) fruits were acquired from the Polytechnic College of the Federal University of Santa Maria (Universidade Federal de Santa Maria - UFSM) in the municipality of Santa Maria, state of Rio Grande do Sul-RS, Brazil. The fruits were washed under running water, disinfected with 200 ppm sodium hypochlorite $(\mathrm{NaClO})$ for 15 minutes, and rinsed. The peels were manually removed using stainless steel knives and were weighed to determine the yield. Material preparation and the physicochemical analyses were performed

\footnotetext{
Received 14 Jan., 2014

Accepted 19 Feb., 2014 (006272)

1 Pharmacy Program, Area of Health Sciences, Franciscan University Center - UNIFRA, Santa Maria, RS, Brazil, e-mail: silvibert@yahoo.com.br

${ }^{2}$ Food Science and Technology Graduate Program, Federal University of Santa Maria - UFSM, Santa Maria, RS, Brazil

${ }^{*}$ Corresponding author
} 
at the Laboratory of Food Science at the Franciscan University Center (Centro Universitário Franciscano - UNIFRA), Santa Maria-RS, Brazil.

After the peels were weighed, they were cut into small pieces. The fractions were then dried in a convection drying oven at $55^{\circ} \mathrm{C}$ for 72 hours and ground using a mill (Tecnal ${ }^{\circledR}$ Willye TE 650). The crushed material was then sieved through a 35 mesh sieve to obtain flour (GPF) with maximum particle size of $500 \mu \mathrm{m}$. The flour was again weighed to calculate the yield, packed in sealed glass containers, and stored at room temperature $24 \mathrm{~h}$ prior to cookie preparation. The characterization assays were performed in triplicate after two days of flour production.

Starting with a basic cookie recipe (Ishimoto et al., 2007) (Table 1), the cookies were prepared with different amounts of wheat flour (WF) and GPF, as shown in Table 2.

For determining the total polyphenol, lycopene, and $\beta$-carotene levels in both the flour and cookies, an extract with $4 \mathrm{~g}$ of dry sample was prepared and added to $40 \mathrm{~mL}$ of $50 \%$ methanol, followed by agitation, 60 -minute rest period, and centrifugation to separate the supernatant. Then, $40 \mathrm{~mL}$ of $70 \%$ acetone was added to the pellet, followed by agitation, 1-hour rest period, and centrifugation. The supernatants were then filtered, transferred to a $100-\mathrm{mL}$ volumetric flask, brought to the

Table 1. Basic cookie recipe.

\begin{tabular}{cc}
\hline Ingredients & Quantities \\
\hline Wheat flour & $180 \mathrm{~g}$ \\
Vanilla & $2 \mathrm{~mL}$ \\
Milk & $35 \mathrm{~mL}$ \\
Butter & $100 \mathrm{~g}$ \\
Sugar & $85 \mathrm{~g}$ \\
Salt & $1 \mathrm{~g}$ \\
Baking powder & $3.5 \mathrm{~g}$ \\
Egg yolk & 1 unit \\
\hline
\end{tabular}

Source: Ishimoto et al. (2007).

Table 2. Content of Wheat flour (WF) and guava peel flour (GPF) used to prepare the cookies.

\begin{tabular}{ccc}
\hline Formulations & WF content (\%) & GPF content (\%) \\
\hline 1 & 70 & 30 \\
2 & 50 & 50 \\
3 & 30 & 70 \\
\hline
\end{tabular}

The physicochemical determinations of the GPF and cookies were performed according to the analytical standards proposed by the Instituto Adolfo Lutz (2008). final volume with distilled water, placed into glass containers, and frozen (Rufino et al., 2007).

The total polyphenol content was determined according to the Singleton and Rossi method (Singleton \& Rossi, 1965) using the Folin-Ciocalteau reagent. The absorbance was read using a spectrophotometer UV/VIS (Pro Analise ${ }^{\circledR}$ UV 1100), in triplicate, at a wavelength of $765 \mathrm{~nm}$. Gallic acid was used as a standard to construct the calibration curve, and the results were expressed in milligrams of gallic acid equivalent (mg GAE) per 100 gram of product.

The lycopene and $\beta$-carotene levels were determined according to Nagata \& Yamashita (1992).The reading was performed in a spectrophotometer UV/VIS (Pro Analise ${ }^{\circledR}$ UV $1100)$ at 453,505 , and $663 \mathrm{~nm}$, and the results were expressed in $\mu \mathrm{g} .100 \mathrm{~mL}^{-1}$.

The sensory analysis of the cookies was performed according to the standards of the Instituto Adolfo Lutz (2008) using an affective test of acceptability based on a five-point hedonic scale (from $1=$ "disliked" to $5=$ "liked a lot") to evaluate the sensory properties of color, aroma, flavor, texture, and appearance. The test was conducted with a total of 56 randomly selected untrained tasters, who received the samples coded; they were also given an informed consent form and the sensory analysis evaluation form. This study was approved by the Research Ethics Committee (Comitê de Ética e Pesquisa - CEP) of UNIFRA under protocol no. 006.2012.2.

The experimental data were obtained using a simple completely randomized design (CRD) with three replicates. The results were expressed as the means \pm standard deviations using a Microsoft ${ }^{\circledR}$ Excel 2007 spreadsheet. An analysis of variance (ANOVA) $(\mathrm{p}<0.05)$ was performed to test the differences between the results. For the statistical analysis, the Tukey's test $(\mathrm{p}<0.05)$ was applied using the SASM-Agri statistical software (Canteri et al., 2001).

\section{Results and discussion}

The proximate composition results of the GPF and the cookies analyzed in this study are shown in Table 3.

There are few studies in the literature on the use of vegetable peels for making flour. No studies were identified in the literature reporting data of proximate composition of guava peel flour; only a few studies on fresh fruit and guava pomace residues were found. This lack of data on GPF may explain the differences observed between the data analyzed and those available in the

Table 3.Average values of proximate composition (g.100 g $\mathrm{g}^{-1}$ ) of guava peel flour (GPF) and different cookie recipes.

\begin{tabular}{lcccc}
\hline \multicolumn{1}{c}{ Analyses } & Flour $($ GPF $)$ & Recipe 1 & Recipe 2 & Recipe 3 \\
\hline Moisture & $7.9 \pm 0.16$ & $2.7 \pm 0.30^{\mathrm{c}}$ & $4.9 \pm 0.27^{\mathrm{b}}$ & $42.1 \pm 2.16^{\mathrm{a}}$ \\
Crude fiber & $15.2 \pm 0.59$ & $2.0 \pm 0.37^{\mathrm{c}}$ & $4.5 \pm 0.24^{\mathrm{a}}$ & $3.8 \pm 0.38^{\mathrm{b}}$ \\
Ash & $11.1 \pm 0.11$ & $3.3 \pm 0.58^{\mathrm{b}}$ & $4.0 \pm 0.18^{\mathrm{a}}$ & $4.2 \pm 0.21^{\mathrm{a}}$ \\
Fat & $1.6 \pm 0.06$ & $5.3 \pm 1.14^{\mathrm{a}}$ & $4.1 \pm 0.89^{\mathrm{b}}$ & $3.8 \pm 1.14^{\mathrm{c}}$ \\
Protein & $6.0 \pm 0.59$ & $4.3 \pm 0.81^{\mathrm{b}}$ & $5.0 \pm 1.43^{\mathrm{a}}$ & $4.8 \pm 0.95^{\mathrm{a}}$ \\
Carbohydrates $^{*}$ & $58.2 \pm 1.92$ & $82.4 \pm 2.92^{\mathrm{a}}$ & $77.5 \pm 2.15^{\mathrm{b}}$ & $41.3 \pm 1.87^{\mathrm{c}}$ \\
\hline
\end{tabular}

Means followed by the same uppercase letter in the same row are not significantly different at $5 \%$ probability level (p<0.05) by Tukey's test. ${ }^{*}$ Carbohydrates calculated by the difference from the other components. Mean values + standard deviation of triplicate determinations and expressed as wet base. 
literature because the flour undergoes prior physical processes, such as heating, which may change its physical and chemical properties.

The moisture content of the flour obtained from the guava peels was $7.9 \mathrm{~g} .100 \mathrm{~g}^{-1}$, which was within the standard required by law (i.e., a maximum of $15 \mathrm{~g} .100 \mathrm{~g}^{-1}[\mathrm{~m} / \mathrm{m}]$ moisture for flour] according to the Brazilian National Health Surveillance Agency (Brasil, 2005). According to El-Dash \& Germani (1994), flours with moisture content above $14 \mathrm{~g} .100 \mathrm{~g}^{-1}$ tend to form lumps, which can affect continuous dough production; flour and water should be mixed evenly in the dough mixture in the manufacturing bakery products.

In a study by Munhoz et al. (2010), the moisture content of flour obtained from guava pulp was $12.55 \mathrm{~g} .100 \mathrm{~g}^{-1}$, and the moisture content of flour obtained from the pulp with guava peel was $13.24 \mathrm{~g} .100 \mathrm{~g}^{-1}$; these results are higher than those obtained in the present study. Fernandes et al. (2008) found the average moisture content of $9.72 \mathrm{~g} .100 \mathrm{~g}^{-1}$ in potato (Solanum tuberosum Lineu) peel flour; a value that is also higher than that of the present study. Souza et al. (2008) found moisture content of 6.09 g. $100 \mathrm{~g}^{-1}$ in passion fruit peel flour; which is lower compared to that of the present study but is in agreement with the maximum value set by ANVISA for flours. In terms of moisture, the GPF value gives exhibited physicochemical stability and long shelflife since it was properly stored (Fertonani et al., 2006).

The moisture levels in the three cookie recipes were significantly different $(\mathrm{p}>0.05)$ between themselves since the moisture content increased as greater amount of GPF was added to the recipe. However, the moisture levels remained within the limits recommended for this type of product in the first two recipes, which had $30 \%$ and 50\% GPF (2.7 and 4.9 g.100 g $\mathrm{g}^{-1}$, respectively). Cookies with low moisture content will have better shelf life conditions if they are packed and stored in properly (i.e., packaging which is impervious to moisture, gases, and preferably with a light barrier). Cookies supplemented with $70 \% \mathrm{GPF}$ had the highest difference in moisture content (42.1 g.100 g $\mathrm{g}^{-1}$ ). This difference is probably due to insufficient baking time (30 minutes). Perez \& Germani (2007) highlighted that as the quantity of eggplant flour increased in crackers, water and fiber content levels also increased, evidencing the high hygroscopicity (high water retention capacity) of the fiber present in the eggplant flour.

The GPF had high fiber content (15.24 g.100 g-1); fiber content also affected the cookies, which had increasing fiber levels with increasing amounts of GPF, except for the third recipe ( $70 \% \mathrm{GPF})$. The three results were significantly different. Souza et al. (2008) found a value of $66.37 \mathrm{~g}$. $100 \mathrm{~g}^{-1}$ fiber in passion fruit peel flour, which is higher than that found in the present study. In contrast, Borges et al. (2009) found $1.01 \mathrm{~g} .100 \mathrm{~g}^{-1}$ fibers in green banana peel flour, which is well lower than the fiber content of GPF. This difference is due to the high moisture content present in cookie 3.

The average ash content of the flour in this study was higher than that reported by Munhoz et al. (2010), who obtained a value of $2.69 \mathrm{~g} .100 \mathrm{~g}^{-1}$ ash in flour made from guava peel and pulp. Boari Lima et al. (2008) found levels of 2.88 and 4.40 g. $100 \mathrm{~g}^{-1}$ of ashes in jaboticaba peel (Myrciaria cauliflora Berg) of varieties Paulista and Sabará, respectively.

Souza et al. (2008) found an ash content of $8.13 \mathrm{~g} .100 \mathrm{~g}^{-1}$ in passion fruit peel flour, and Fasolin et al. (2007) obtained only $2.62 \mathrm{~g} .100 \mathrm{~g}^{-1}$ ash in a study with green banana flour; Martínez et al. (2012) found $2.4 \mathrm{~g} .100 \mathrm{~g}^{-1}$ in the co-products (peel, pulp, and seed) of guava (cv. Paluma). These studies suggest that the proximate compositions of plants differ according to fruit botanical classification, soil type, edaphoclimatic conditions, and others. Gondim et al. (2005) suggest that fruit peels exhibit more minerals than their edible parts, which explains the significant mineral contents obtained in this study.

The ash contents in the cookies were significantly different; the ash contents in the recipes increased with the increasing amounts of GPF added to the product. In cookies supplemented with macambira (Bromelia lacioniosa) flour, the ash content was $1.95 \mathrm{~g} .100 \mathrm{~g}^{-1}$, lower than the results obtained in this study (Farias et al., 2011). GPF had low fat content $\left(1.63 \mathrm{~g} .100 \mathrm{~g}^{-1}\right)$, which is similar to the results reported by Souza et al. (2008) (1.64 g. $\left.100 \mathrm{~g}^{-1}\right)$ for passion fruit peel flour and also similar to the results reported by Fernandes et al. (2008) (1.61 g.100 g $\left.\mathrm{g}^{-1}\right)$ for potato skin flour. In a study by Uchoa et al. (2008), the lipid contents for edible powders of cashew and guava pomace residues were 3.03 and $9.74 \mathrm{~g} .100 \mathrm{~g}^{-1}$, respectively. In contrast, these authors detected only $0.75 \mathrm{~g} .100 \mathrm{~g}^{-1}$ fat in an edible powder obtained from passion fruit peels, which is much lower than the value found in this study. Despite this significant difference, the fat value decreased in the cookies when greater amount of wheat flour was replaced with guava peel flour, demonstrating that this replacement potentially reduces this product fat content.

Perez \& Germani (2007) prepared cookies using eggplant flour and noted increasing fat contents (18.11, 19.07, and $21.33 \%$ ) when greater amount of wheat flour was replaced with eggplant flour (10\%, 15\%, and 20\%), values that are much higher than those obtained in this study. In cookies supplemented with macambira flour, the lipid content was found to be $7.97 \%$, which is also higher than the value obtained in this study (Farias et al., 2011).

The protein content of GPF in this study was higher than the crude protein contents of edible powders from passion fruit peels $(0.96 \%)$ and cashew and guava pomace residues $(1.16 \%$ each) (Uchoa et al., 2008). As shown in Table 3, there was no significant difference between the formulations 2 and 3 had $(\mathrm{p}<0.05)$, but they differed from formulation 1 . The results obtained demonstrate that the cookies made with the largest concentrations of GPF had the greatest protein levels, which is directly related to the high protein content of the flour. The protein content of $6.78 \mathrm{~g} .100 \mathrm{~g}^{-1}$ found by Aquino et al. (2010) for the cookies made with $10 \%$ flour made from acerola waste (Malpighia glabra L.) is higher than the values obtained for the cookies in the present study. Nevertheless, these authors also found that the greatest protein source in biscuits was related to the high protein content of the acerola residue flour (8.88 g. $\left.100 \mathrm{~g}^{-1}\right)$.

The carbohydrate content of GPF was lower than that reported by Souza et al. (2008) in passion fruit peel flour $\left(77.07\right.$ g. $\left.100^{-1}\right)$, but the values obtained were higher than those 
reported by Martínez et al. (2012) for a co-product of guava $\left(22.2 \mathrm{~g} 100 \mathrm{~g}^{-1}\right)$. There were significant differences between the values found for the cookies since the carbohydrate levels decreased when greater amount of wheat flour was replaced with GPF. In contrast, Costa et al. (2012) observed high carbohydrate values without significant differences in cookies supplemented with passion fruit powder. Perez \& Germani (2007) also observed decreased carbohydrate percentages with increasing proportions of eggplant flour in crackers.

Compared to other flours, GPF has good nutritional value, especially regarding its mineral and crude fiber levels. According to Fasolin et al. (2007), green banana flour had 7.55\% moisture content, $2.62 \%$ ash, $4.54 \%$ protein, and $1.89 \%$ lipids, while dehydrated juazeiro (Ziziphus joazeiro Mart.) fruit flour (Cavalcanti et al., 2011) had $8.53 \%$ moisture content, $4.32 \%$ ash, $5.57 \%$ protein, $1.13 \%$ lipids, and $80.45 \%$ total carbohydrates.

The phenolic compound levels are shown in Table 4. GPF had high phenolic content that decreased considerably during the chemical and physical processes of cookie preparation. Increased quantities of GPF in the cookies resulted in significant increases in phenolic compounds. Comparing the results of this study with those of the literature, lower phenolic compound values were obtained by Chen et al. (2007) for the aqueous extract of guava leaves ( $154.36 \mathrm{mg} \mathrm{GAE} .100 \mathrm{~g}^{-1}$ ) and by Lim et al. (2007) for seeded guava fruit (138.0 mg GAE.100 g $\mathrm{g}^{-1}$ ) and seedless guava fruit $\left(179.0 \mathrm{mg} \mathrm{GAE} \cdot 100 \mathrm{~g}^{-1}\right)$. Kuskoski et al. (2006) found $83.0 \mathrm{mg}$ GAE.100 $\mathrm{g}^{-1}$ of phenolic compounds in guava pulp, which is much lower than that found in this study for GPF, while Vasco et al. (2008) obtained $462.0 \mathrm{mg} .100 \mathrm{~g}^{-1}$ in guava fruits. In general, the content of phenolic compounds present in fruits is higher than in the leaves, mainly because they are ascorbic acid-rich; these variations may be due to differences in varieties, climate, and extraction method (Kuskoski et al. 2006). In a study on four mango varieties grown in Brazil, discrepant levels of phenolic compounds were found (from 48.40 to $208.70 \mathrm{mg} .100 \mathrm{~g} \mathrm{~g}^{-1}$ ) between the varieties analyzed, demonstrating that variety is a determining factor for phenolic content levels (Ribeiro et al., 2007).
The $\beta$-carotene content present in GPF was $37.76 \mu \mathrm{g} .100 \mathrm{~g}^{-1}$. In the cookie recipes, only formulation 3 differed statistically compared the other formulations (Table 4). The lycopene content in GPF was $26.72 \mu \mathrm{g} 100 \mathrm{~g}^{-1}$; lycopene levels did not significantly differ in the cookie recipes as GPF inclusion increased. The differences in the levels of licopene and $\beta$-carotene may be partially explained by problems with bioavailability of lycopene from different food sources, as some types of fibers found in foods, such as pectin, can reduce the bioavailability of lycopene (Shi \& Maguer, 2000).

Oliveira et al. (2011) reported much higher lycopene levels $\left(6999.3 \mu \mathrm{g} .100 \mathrm{~g}^{-1}\right)$ in fresh and whole guava fruit compared to this study. This difference is possibly due to either the thermal processing used to obtain the flour or a greater amount of lycopene being present in the pulp than in the guava peels. Oliveira et al. (2011) also quantified the $\beta$-carotene in guava and reported values of $366.3 \mu \mathrm{g} .100 \mathrm{~g}^{-1}$, while Freire et al. (2012) measured $490 \mu \mathrm{g} .100 \mathrm{~g}^{-1}$ in guava, which is also higher than the value measured in this study.

The results of sensory analysis in the three cookie recipes with GPF added are shown in Table 5. The hedonic values were placed incrementally ( 1 corresponds to the hedonic term "disliked", and 5 corresponds to the term "liked a lot"), and the mean scores for each recipe in relation to each of the sensory attributes analyzed are shown. In general, the results of the sensory analysis demonstrated satisfactory acceptance of cookies for most of the parameters studied, considering that most of the mean scores are above 3 (indifferent). The flavor parameters exhibited significant differences: the sample from the $30 \%$ e $50 \%$ guava flour recipe was most accepted for flavor, with a 3.8 and 3.2 score, respectively (liked), and the sample from the $70 \%$ GPF was least accepted, with a 2.5 score (liked a little).

In the study by Mauro et al. (2010), sensory analysis tests in cookies prepared with kale stalk flour and spinach stalk flour demonstrated that partially replacing wheat flour does not alter the sensory characteristics or product acceptability and also make the cookie more nutritious. Costa et al. (2012) demonstrated that enriching cookies with passion fruit powder

Table 4.Total polyphenol content (mg GAE. $100 \mathrm{~g}^{-1}$ ), lycopene, and $\beta$-carotene ( $\mu \mathrm{g} \cdot 100 \mathrm{~g}^{-1}$ for both) in guava peel flour (GPF) and in the different cookie recipes tested.

\begin{tabular}{cccc}
\hline GPF and Cookies & Total polyphenols & Lycopene & $\beta$-carotene \\
\hline Flour & $827.0 \pm 8.33$ & $26.72 \pm 1.46$ & $37.76 \pm 0.26$ \\
Recipe 1 & $68.7 \pm 5.20^{\mathrm{c}}$ & $28.66 \pm 0.60^{\mathrm{ns}}$ & $12.09 \pm 0.34^{\mathrm{b}}$ \\
Recipe 2 & $123.3 \pm 7.11^{\mathrm{b}}$ & $26.90 \pm 0.45^{\mathrm{ns}}$ & $11.48 \pm 0.49^{\mathrm{b}}$ \\
Recipe 3 & $136.2 \pm 3.72^{\mathrm{a}}$ & $25.96 \pm 0.91^{\mathrm{ns}}$ & $14.93 \pm 0.10^{\mathrm{a}}$ \\
\hline
\end{tabular}

Only for cookie recipes: means followed by the same uppercase letter in the same column do not significantly differ from each other by Tukey's test at $5 \%$ probability ( $<0.05$ ). ns - nonsignificant.

Table 5. Mean acceptance scores in relation to the sensory attributes in the different cookie recipes.

\begin{tabular}{|c|c|c|c|c|c|}
\hline \multirow{2}{*}{ Cookies } & \multicolumn{5}{|c|}{ Sensory attribute } \\
\hline & Color & Smell & Flavor & Texture & Appearance \\
\hline Recipe 1 & $3.2 \pm 1.1^{\mathrm{ns}}$ & $3.6 \pm 1.1^{\mathrm{ns}}$ & $3.8 \pm 1.3^{\mathrm{a}}$ & $3.1 \pm 1.3^{\mathrm{ab}}$ & $3.5 \pm 1.2^{\text {ns }}$ \\
\hline Recipe 2 & $3.4 \pm 1.2^{\mathrm{ns}}$ & $3.7 \pm 1.1^{\mathrm{ns}}$ & $3.2 \pm 1.5^{\mathrm{a}}$ & $3.4 \pm 1.2^{\mathrm{a}}$ & $3.5 \pm 1.3^{\mathrm{ns}}$ \\
\hline Recipe 3 & $3.1 \pm 1.3^{\mathrm{ns}}$ & $3.5 \pm 1.1^{\mathrm{ns}}$ & $2.5 \pm 1.4^{\mathrm{b}}$ & $2.7 \pm 1.3^{\mathrm{b}}$ & $3.1 \pm 1.4^{\mathrm{ns}}$ \\
\hline
\end{tabular}

Means by the same uppercase in the same column do not significantly differ from each other by Tukey's test at $5 \%$ probability ( $\mathrm{p}<0.05)$. ns - not significant. 
Table 6. Acceptability indices for the cookie recipes.

\begin{tabular}{cccccc}
\hline \multirow{2}{*}{ Cookies } & \multicolumn{3}{c}{ Acceptability index (\%) } \\
\cline { 2 - 5 } & Color & Aroma & Flavor & Texture & Appearance \\
\hline Recipe 1 & 63.40 & 71.32 & 76.60 & 61.13 \\
Recipe 2 & 67.55 & 73.96 & 64.15 & 67.92 & 69.81 \\
Recipe 3 & 61.89 & 70.19 & 50.57 & 53.21 & 62.64 \\
\hline
\end{tabular}

does not cause loss of sensory quality and improves the product's nutritional quality.

Table 6 shows the cookie acceptance indices. According to Bispo et al. (2004), acceptability index values higher than $70 \%$ are considered good. As for the indices found in this study, the cookie enriched with 30\% GPF obtained good acceptability index for aroma (71.32\%), flavor $(76.60 \%)$, and appearance (70.19\%), while the cookies enriched with 50\% and 70\% GPF obtained good acceptability index only for aroma (73.96\% and $70.19 \%$, respectively).

\section{Conclusions}

The use of GPF to partially replace wheat flour in the preparation of cookies has several nutritional advantages: decreased levels of fat and carbohydrates and increased amounts of fiber and protein. GPF showed a significant content of total polyphenols, lycopene, and $\beta$-carotene, which were preserved during processing. The increase in the amount of GPF resulted in an increase of phenol and $\beta$-carotene content in the product. There was no statistical difference in the lycopene content between the formulations. In terms of sensory qualities, the increase in GPF levels did not result in differences in the parameters color, flavor, and appearance; whereas flavor was positively affected by the increase in GPF amount. With regard to the acceptability index, the flour aroma was very well accepted (greater than $70 \%$ for all formulations); the addition of GPF affected the color, flavor, texture and appearance parameters. The results presented here indicate that GPF can be used in cookies, partially replacing wheat flour to improve its nutritional quality without affecting the product sensory quality.

\section{References}

Aquino, A. C. M. S., Móes, R. S., Leão, K. M. M., Figueiredo, A. V. D., \& Castro, A. A. (2010). Avaliação físico-química e aceitação sensorial de biscoitos tipo cookies elaborados com farinha de resíduos de acerola. Revista do Instituto Adolfo Lutz, 69(3), 379-386.

Assis, L. M., Zavareze, E. R., Raünz, A. L., Dias, A. R. G., Gutkoski, L. C., \& Elias, M. C. (2009). Propriedades nutricionais, tecnológicas e sensoriais de biscoitos com substituição de farinha de trigo por farinha de aveia ou farinha de arroz parboilizado. Alimentos e Nutrição, 20(1), 15-24.

Bispo, E. S., Santana, L. R., Carvalho, R. D., Andrade, G., \& Leite, C. C. (2004). Aproveitamento industrial de marisco na produção de linguiça. Food Science and Techonology, 24(4), 664-668.

Boari Lima, A. J., Corrêa, A. D., Alves, A. P. C., Abreu, C. M. P., \& Dantas-Barros, A. M. (2008). Caracterização química do fruto jabuticaba (Myrciaria cauliflora Berg) e de suas frações. Archivos Latinoamericanos de Nutrición, 58(4), 416-421.
Borges, A. M., Pereira, J., \& Lucena, E. M. (2009). Caracterização da farinha da banana verde. Food Science and Techonology, 29(2), 333-339.

Brasil. Ministério da Saúde, Agência Nacional de Vigilância Sanitária. (2005). Aprova o regulamento técnico para produtos de cereais, amidos, farinhas e farelos (Resolução RDC n 263, de 22 de setembro de 2005). Diário Oficial da República Federativa do Brasil. Retrieved from http://portal.anvisa.gov.br/wps/wcm/connect/9864778045 c9883b962bf6d7a095f735/RDC_263_2005.pdf;MOD=AJPERES

Canteri, M. G., Althaus, R. A., Virgens Filho, J. S., \& Giglioti, E. A. (2001).SASM-Agri: sistema para análise e separação de médias em experimentos agrícolas para métodos Scott-Knott, Tukey e Duncan. Revista Brasileira de Agrocomputação, 1(2), 18-24.

Cavalcanti, M. T., Silveira, D. C., Florêncio, I. M., Feitosa, V. A., \& Eller, S. C. S. W. (2011). Obtenção da farinha do fruto do juazeiro (Ziziphus joazeiro Mart) e caracterização físico-química. Revista Verde, 6(1), 220-224.

Chen, H. Y., Lin, Y. C., \& Hsieh, C. L. (2007). Evaluation of antioxidant activity of aqueous extract of some selected nutraceutical herbs. Food Chemistry, 104(4), 1418-1424. http://dx.doi.org/10.1016/j. foodchem.2007.02.004

Costa, J. N., Soares, D. J., Carneiro, A. P., Moura, S. M., Rodrigues, C. S., \& Figueiredo, W. (2012). Composição centesimal e avaliação sensorial de biscoito tipo cookies acrescido de maracujá em pó. Revista Brasileira de Produtos Agroindustriais, 14(2), 143-147.

El-Dash, A., \& Germani, R. (1994). Tecnologia de farinhas mistas: uso de farinha mista de trigo e milho na produção de pães (Vol. 2). Brasília: EMBRAPA.

Farias, N. S., Cavalcanti, M. T., Eller, S. C., \& Florentino, E. R. (2011). Elaboração de biscoitos tipo cookie enriquecido com macambira (Bromelia laciniosa). Revista Verde de Agroecologia e Desenvolvimento Sustentável, 6(4), 50-67.

Fasolin, L. H., Almeida, G. C., Castanho, P. S., \& Netto-Oliveira, E. R. (2007). Biscoitos produzidos com farinha de banana: avaliações química, física e sensorial. Food Science and Techonology, 27(3), 524-529.

Fernandes, A. F., Pereira, J., Germani, R., \& Oiano-Neto, J. (2008). Efeito da substituição parcial da farinha de trigo por farinha de casca de batata (Solanum tuberosum Lineu). Food Science and Techonology, 28, 56-65.

Fertonani, H. C. R., Scabio, A., Schemin, M. H. C., Carneiro, E. B. B., Nogueira, A., \& Wosiacki, G. (2006). Influência da concentração de ácidos no processo de extração e na qualidade de pectina de bagaço de maçã. Semina: Ciências Agrárias, 27(4), 599-612. http://dx.doi. org/10.5433/1679-0359.2006v27n4p599

Freire, J. M., Abreu, C. M. P., Corrêa, A. D., Simão, A. A., \& Santos, C. M. (2012). Avaliação de compostos funcionais e atividade antioxidante em farinhas de polpa de goiaba. Revista Brasileira de Fruticultura, 34(3), 847-852. http://dx.doi.org/10.1590/S010029452012000300026

Gondim, J. A., Moura, M. F., Dantas, A. S., Medeiros, R. L. S., \& Santos, K. M. (2005). Composição centesimal e de minerais em cascas de frutas. Food Science and Techonology, 25(4), 825-827. 
Instituto Adolfo Lutz. (2008). Métodos físico-químicos para análise de alimentos. São Paulo: IAL. Retrieved from http://www.ial.sp.gov. br/index.php?option=com_remository\&Itemid $=7 \&$ func $=$ select $\&$ orderby $=1 \&$ Itemid $=7$

Ishimoto, F. Y., Harada, A. I., Branco, I. G., Conceição, W. A. S., \& Coutinho, M. R. (2007). Aproveitamento alternativo da casca do Maracujá-Amarelo (Passiflora edulis var. flavicarpaDeg.) para produção de biscoitos. Revista Ciências Exatas e Naturais, 9(2), 279-292.

Kobori, C. N., \& Jorge, N. (2005). Caracterização dos óleos de algumas sementes de frutas como aproveitamento de resíduos industriais. Ciência e Agrotecnologia, 29(5), p. 1008-1014. http://dx.doi. org/10.1590/S1413-70542005000500014

Kuskoski, E. M., Asuero, A. G., Morales, M. T., \& Fett, R. (2006). Frutos tropicais silvestres e polpas de frutas congeladas: atividade antioxidante, polifenóis e antocianinas. Ciência Rural, 36(4), 12831287. http://dx.doi.org/10.1590/S0103-84782006000400037

Lim, Y. Y., Lim, T. T., \& Tee, J. J. (2007). Antioxidant properties of several tropical fruits: a comparative study. Food Chemistry, 103(3), 10031008. http://dx.doi.org/10.1016/j.foodchem.2006.08.038

Martínez, R., Torres, P., Meneses, M. A., Figueroa, J. G., Pérez-Álvarez, J. Á., \& Viuda-Martos M. (2012). Chemical, technological and in vitro antioxidant properties of mango, guava, pineapple and passion fruit dietary fibre concentrate. Food Chemistry, 135(3), 1520-1526. PMid:22953888. http://dx.doi.org/10.1016/j.foodchem.2012.05.057

Mauro, A. K., Silva, V. L. M., \& Freitas, M. C. J. (2010). Caracterização física, química e sensorial de cookies confeccionados com farinha de talo de couve (FTC) e farinha de talo de espinafre (FTE) ricas em fibra alimentar. Food Science and Techonology, 30(3), 719-728.

Munhoz, C. L., Sanjinez-Argandoña, E. J., \& Soares-Junior, M. S. (2010). Extração de pectina de goiaba desidratada. Food Science and Techonology, 30(1), 119-125.

Nagata, M., \& Yamashita, I. (1992). Simple method for simultaneous determination of chlorophyll and carotenoids in tomato fruit. Nippon Shokuhin Kogyo Gakkaishi, 39(10), 925-928. http://dx.doi. org/10.3136/nskkk1962.39.925

Oliveira, D. S., Aquino, P. P., Ribeiro, S. M., Proença, R. P., \& PinheiroSant'Ana, H. M. P. (2011). Vitamina C, carotenóides, fenólicos totais e atividade antioxidante de goiaba, manga e mamão procedentes da Ceasa do Estado de Minas Gerais. Acta Scientiarum: Health Sciences, 33(1), 89-98.

Perez, P. M. P., \& Germani, R. (2007). Elaboração de biscoitos tipo salgado, com alto teor de fibra alimentar, utilizando farinha de berinjela (Solanum melongena, L). Food Science and Techonology, 27(1), 186-192.

Ribeiro, S. M. R., Queiroz, J. H., Queiroz, M. E. R. L., Campos, F. M., \& Pinheiro-Sant'Ana, H. M. (2007). Antioxidants in mango (Mangifera indica, L.). Plant Foods for Human Nutrition, 62(1), 1317. PMid:17243011. http://dx.doi.org/10.1007/s11130-006-0035-3

Rufino, M. S., Alves, R. E., Brito, E. S., Moraes, S. M., Sampaio, C. G., Pérez-Jiménez J., \& Saura-Calixto, F. D. (2007). Metodologia científica: determinação da atividade antioxidante total em frutas pela captura do radical ABTS. Fortaleza: Embrapa Agroindústria Tropical. Comunicado Técnico 127.

Santucci, M. C. C., Alvim, I. D., Faria, E. V., \& Sgarbieri, V. C. (2003). Efeito do enriquecimento de biscoitos tipo água e sal com extrato de levedura (Saccharomyces sp.). Ciência e Tecnologia de Alimentos, 23(3), 441-446. http://dx.doi.org/10.1590/S010120612003000300025

Shi, J., \& Maguer, M. L. (2000). Lycopene in tomatoes: chemical and physical properties affected by food processing. Critical Reviews in Biotechnology, 20(4), 293-334. PMid:11192026. http://dx.doi. org/10.1080/07388550091144212

Singleton, V. L., \& Rossi, J. A. (1965). Colorimetry of total phenolics with phosphomolybdic-phosphotungstic acid reagents. American Journal of Enology and Viticulture, 20(3), 144-158.

Souza, M. W., Ferreira, T. B., \& Vieira, I. F. (2008). Composição centesimal e propriedades funcionais tecnológicas da farinha da casca do maracujá. Alimentos e Nutrição, 19(1), 33-36.

Uchoa, A. M., Costa, J. C., Maia, G. A., Silva, E. M. C. S., Carvalho, A. F. F. U., \& Meira, T. R. (2008). Parâmetros físico-químicos, teor de fibra bruta e alimentar de pós alimentícios obtidos de resíduos de frutas tropicais. Segurança Alimentar e Nutricional, 15(2), 58-65

Vasco, C., Ruales, J., \& Kamal-Eldin, A. (2008). Total phenolic compounds and antioxidant capacities of major fruits from Ecuador. Food Chemistry, 111(4), 816-823. http://dx.doi.org/10.1016/j. foodchem.2008.04.054 